\title{
Shifting the $\mathrm{pH}$ Profile of Aspergillus niger PhyA Phytase To Match the Stomach $\mathrm{pH}$ Enhances Its Effectiveness as an Animal Feed Additive
}

\author{
Taewan Kim, ${ }^{1}$ Edward J. Mullaney, ${ }^{2}$ Jesus M. Porres, ${ }^{1}$ Karl R. Roneker, ${ }^{1}$ Sarah Crowe, ${ }^{1}$ Sarah Rice, ${ }^{1}$ \\ Taegu Ko, ${ }_{1}$ Abul H. J. Ullah, ${ }^{2}$ Catherine B. Daly, ${ }^{2}$ Ross Welch, ${ }^{3}$ and Xin Gen Lei ${ }^{1 *}$ \\ Department of Animal Science, Cornell University, Ithaca, New York 14853'; Southern Regional Research Center, \\ Agricultural Research Service, United States Department of Agriculture, New Orleans, Louisiana 70124²; and \\ Soil and Nutrition Laboratory, United States Department of Agriculture, Ithaca, New York $14853^{3}$
}

Received 5 November 2005/Accepted 4 April 2006

\begin{abstract}
Environmental pollution by phosphorus from animal waste is a major problem in agriculture because simple-stomached animals, such as swine, poultry, and fish, cannot digest phosphorus (as phytate) present in plant feeds. To alleviate this problem, a phytase from Aspergillus niger PhyA is widely used as a feed additive to hydrolyze phytate-phosphorus. However, it has the lowest relative activity at the pH of the stomach (3.5), where the hydrolysis occurs. Our objective was to shift the pH optima of PhyA to match the stomach condition by substituting amino acids in the substrate-binding site with different charges and polarities. Based on the crystal structure of PhyA, we prepared 21 single or multiple mutants at Q50, K91, K94, E228, D262, K300, and K301 and expressed them in Pichia pastoris yeast. The wild-type (WT) PhyA showed the unique bihump, two-pH-optima profile, whereas 17 mutants lost one $\mathrm{pH}$ optimum or shifted the pH optimum from pH 5.5 to the more acidic side. The mutant E228K exhibited the best overall changes, with a shift of pH optimum to 3.8 and $266 \%$ greater $(P<0.05)$ hydrolysis of soy phytate at $\mathrm{pH} 3.5$ than the WT enzyme. The improved efficacy of the enzyme was confirmed in an animal feed trial and was characterized by biochemical analysis of the purified mutant enzymes. In conclusion, it is feasible to improve the function of PhyA phytase under stomach pH conditions by rational protein engineering.
\end{abstract}

Phytases are phosphohydrolytic enzymes that initiate the stepwise removal of phosphate from phytate (myo-inositol hexakisphosphate), the major form of phosphorus in plant foods or feeds (28). Simple-stomached animals, such as swine, poultry, fish, and preruminant calves, do not have phytases in their gastrointestinal tracts and cannot digest phytate-phosphorus. Consequently, there are three major problems (1, 7, 41). First, the unutilized feed phosphorus ends up in manure, causing serious environmental pollution in areas of intensive animal husbandry. Second, it is necessary to supplement inorganic phosphorus in diets for swine, poultry, and fish to meet their nutrient requirement for phosphorus. This represents a significant expense in animal feeding. Third, inorganic phosphorus is nonrenewable, and the easily accessible inorganic phosphorus on earth may be exhausted in 80 years at the current rate of extraction (1). In addition, phytate can chelate trace elements, such as iron and zinc, causing widespread deficiencies of these nutrients in populations whose staple foods are legume based $(18,26)$.

Low-phytate plants (33) and phytase-transgenic plants (15, 40) or animals (7) have been developed to cope with the nutritional and environmental problems associated with phytate-phosphorus. Although these approaches represent remarkable scientific advances, they are limited in practical application. In contrast, microbial phytases have become a widely

\footnotetext{
* Corresponding author. Mailing address: Department of Animal Science, Cornell University, Ithaca, NY 14853. Phone: (607) 254-4703. Fax: (607) 255-9829. E-mail: XL20@Cornell.edu.
}

accepted and highly effective tool for animal industry to improve feed phytate-phosphorus bioavailability to animals and to comply with environmental laws restricting phosphorus excretion in animal waste. Numerous animal experiments have shown that adding phytase to feed at 500 to 1,000 units $\mathrm{kg}^{-1}$ may replace inorganic-phosphorus supplements for pigs and poultry and reduce their phosphorus excretion by approximately $50 \%(2,13,14)$.

Aspergillus niger PhyA is the first commercialized phytase, and it occupies a good share of the world market with a $\$ 500$ million potential (1). Although the enzyme has good catalytic efficacy (14), its unique $\mathrm{pH}$ profile precludes it from full function in the stomachs of animals, where dietary phytate-phosphorus is hydrolyzed (38). Specifically, it has two $\mathrm{pH}$ optima, 5 to $5.5(100 \%)$ and $2.5(60 \%)$, and a trough in activity at $\mathrm{pH} 3.5$ $(22,38)$. The stomach $\mathrm{pH}$ in many species is around 3.5 (42), which happens to be the lowest activity point in the $\mathrm{pH}$ profile of PhyA (22). Thus, a relatively high level of phytase supplementation is required in animal diets for adequate hydrolysis of phytate-phosphorus $(13,14)$.

Limited success has been achieved in altering the $\mathrm{pH}$ profiles of xylanase, $\alpha$-amylase, glucoamylase, glycosidase, subtilisin, pepsin, and chymotrypsin by protein engineering $(4,5,6,9,19$, $23,32,37)$. Approaches used include replacing the amino acid residues in or near the active site, changing the $\mathrm{pK}_{\mathrm{a}}$ value of the catalytic amino acid residue acting as a general base catalyst $(4,5,6,9,19,23,37)$, and modifying the enzyme surface charge $(32,36)$. However, all of these efforts have been almost exclusively focused on improvement of the in vitro functions of the enzymes. The feasibility of shifting the optimal $\mathrm{pH}$ of 

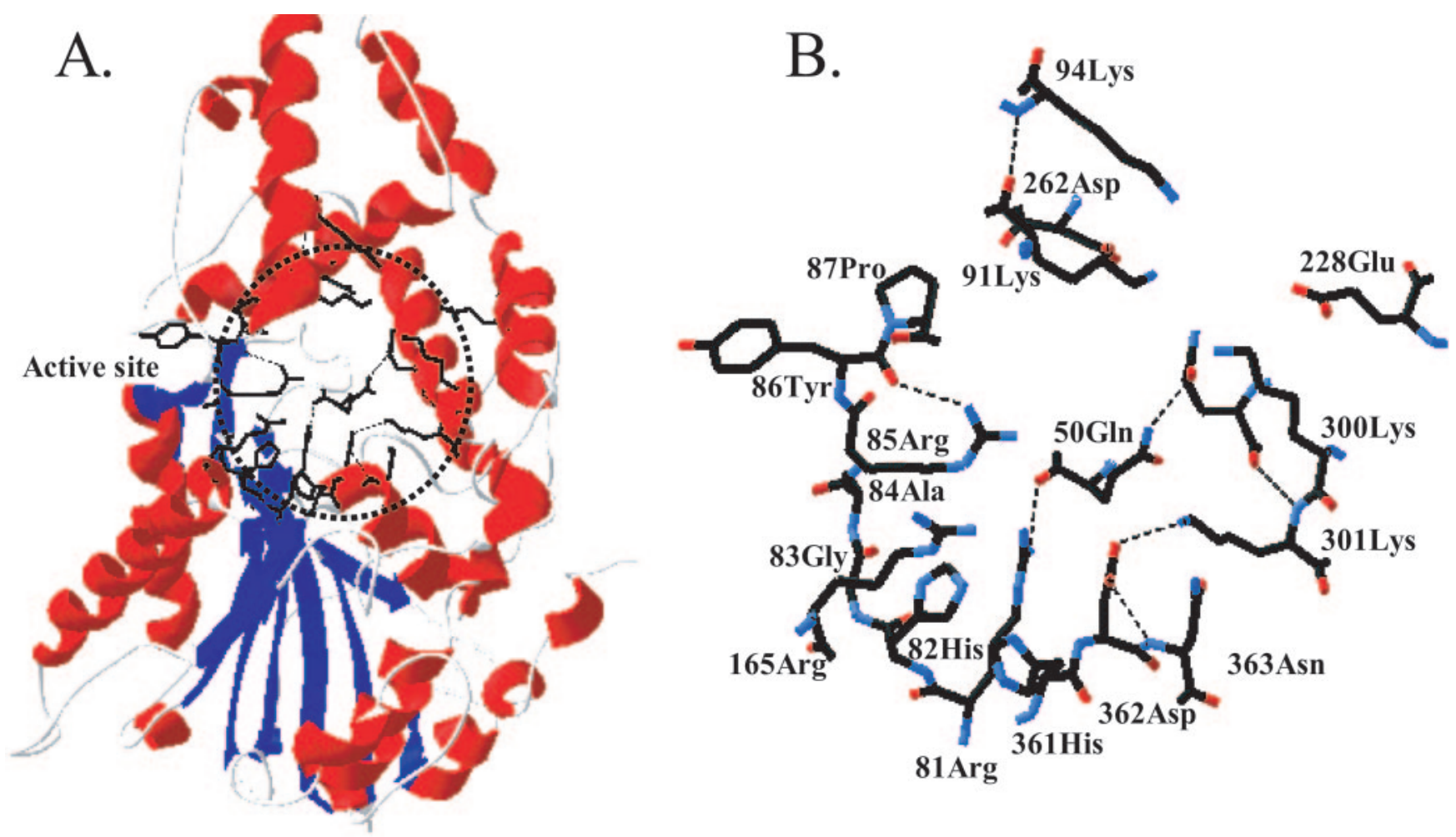

FIG. 1. (A) The region of the mutated amino acids (dotted circle) in the three-dimensional structure of $A$. niger PhyA. (B) The seven mutated amino acids (Q50, K91, K94, E228, D262, K300, and K301) and related amino acids in the circled region of panel A. The structure is based on Kostrewa et al. (10). The $\alpha$-helices are shown in red and the $\beta$-sheets in blue in panel A; dotted lines represent hydrogen bonds in panel B.

phytase or any given enzyme to match the stomach conditions has not been determined. Strategically, the effect of modification of amino acid residues involved in substrate binding on the enzyme's pH profile has not been well studied. Based on the kinetics and structure of PhyA and other phytases (10, 11, 16, 24,25 ), amino acid residues in the $\alpha$-domain (K91, K94, E228, D262, K300, and K301) are involved in substrate binding (11, 21). As the $\mathrm{pH}$ profile of a given enzyme is generally determined by the ionization of the catalytic groups and is affected by various interactions involved in their microenvironments of enzyme and substrate, the unique activity drop of PhyA at $\mathrm{pH}$ 3.5 may be due to the interaction of these acidic and basic amino acids comprising the substrate specificity site (22). While the clustering of K91, K94, K300, K301, and other basic amino acids (R81, H82, R85, K165, and H361) $(11,21)$ around the active site of PhyA presumably creates a relatively favorable electrostatic environment for binding the highly negatively charged substrate phytate, it remains to be determined how alterations of biochemical properties in each of these amino acid positions actually affect the $\mathrm{pH}$-activity profile and substrate affinity of PhyA. In addition, Q50 is located in the active site and has been shown to affect $\mathrm{pH}$-activity profiles in other phytases (35). Therefore, the objective of the present study was to determine the impact of changing these seven selected amino acid residues into substitutes with different charges, polarities, and/or side chain lengths on the $\mathrm{pH}$-activity profile of PhyA.

\section{MATERIALS AND METHODS}

Construction of phy $\boldsymbol{A}$ mutants. Plasmid pYPP1, containing the $A$. niger NRRL3135 phy A gene cloned into a Saccharomyces cerevisiae expression vector, pYES2, was employed to generate the mutations (8). A total of 9 single and 12 multiple mutants at positions Q50, K91, K94, E228, D262, K300, and K301 (Fig. 1) were prepared by introducing different charges, polarities, or side chain lengths (Table 1). Oligonucleotides were synthesized to generate site-specific mutations at substrate binding sites described earlier (22). The phyA mutants in pYPP1 were constructed using the Gene Editor In Vitro Site-Directed Mutagenesis System (Promega, Madison, WI) (22). The coding region of the pYPP1 mutant construct was amplified by PCR using two primers (upstream, 5'CGG AAT TCC TGG CAG TCC CCG3'; downstream, 5'GCT CTA GAC TAA GCA AAA CAC TCC3') and inserted into a constitutive expressing vector, pGAPZ $\alpha$ A (Invitrogen, San Diego, $\mathrm{CA}$ ), at EcoRI and XbaI sites. The gene was led by a signal peptide $\alpha$-factor and was under the control of the GAP promoter. The desired mutations in the selected transformants were confirmed by DNA sequencing.

Transformation, phytase expression, and protein purification. The pGAP vector containing the phy $A$ mutant gene $(10 \mu \mathrm{g})$ was linearized by the restriction enzyme BamHI and transformed into Pichia pastoris X33 by electroporation using an ECM 600 Electro Cell Manipulator (Gentronics, Inc., BTX Instrument Division, San Diego, CA). The transformed cells were plated in YPD agar (1\% yeast extract, $2 \%$ peptone, and $2 \%$ dextrose) plus zeocin $\left(100 \mu \mathrm{g} \mathrm{ml} \mathrm{m}^{-1}\right)$ and incubated at $30^{\circ} \mathrm{C}$ for 3 days. Single colonies of the transformants were inoculated into YPD media and incubated at $30^{\circ} \mathrm{C}$ for 2 days for phytase expression. Phytase activity in the culture supernatant was measured to select the best transformants with high phytase expression. The expressed enzymes in the medium supernatant were sequentially purified by ultrafiltration (molecular weight cutoff, 30,000) and DEAE-cellulose column (10 mM Tris- $\mathrm{HCl}$ buffer, $\mathrm{pH} 7.4$, with an $\mathrm{NaCl}$ linear gradient) and Sephadex G-100 gel exclusion column (50 mM Tris- $\mathrm{HCl}$ buffer containing $0.15 \mathrm{M} \mathrm{NaCl}, \mathrm{pH}$ 7.4) chromatography (8). The purified phytase was eluted as a single peak and used for further analysis.

Phytase activity, protein, and $\mathbf{p H}$ profile assays. Phytase activity was measured using sodium phytate as the substrate. One phytase unit was defined as the 
TABLE 1. $\mathrm{pH}$ optima and activity ratios of PhyA mutants at different $\mathrm{pH}$ pairs

\begin{tabular}{|c|c|c|c|c|}
\hline \multirow{2}{*}{ Mutant } & \multicolumn{2}{|c|}{ Optimal $\mathrm{pH}^{a}$} & \multicolumn{2}{|c|}{ Ratio of activity ${ }^{b}$} \\
\hline & First & Second & $\mathrm{pH} 3.5 / 5.5$ & pH $3.5 / 2.5$ \\
\hline WT & $5-5.5$ & $2.5(67)$ & $0.38 \pm 0.01$ & $0.55 \pm 0.03$ \\
\hline Q50L & 5.0 & & $0.68 \pm 0.01 *$ & $1.51 \pm 0.03 *$ \\
\hline $\mathrm{Q} 50 \mathrm{P}$ & 5.5 & $3.0(61)$ & $0.50 \pm 0.01 *$ & $0.94 \pm 0.02 *$ \\
\hline K91A & $5-5.5$ & $2.5(60)$ & $0.33 \pm 0.00^{*}$ & $0.55 \pm 0.00$ \\
\hline K91E & $5-5.5$ & & $0.46 \pm 0.03^{*}$ & $1.76 \pm 0.11^{*}$ \\
\hline K94E & $5-5.5$ & $2.0(69)$ & $0.34 \pm 0.01^{*}$ & $0.56 \pm 0.01$ \\
\hline E228Q & $5-5.5$ & $2.5(66)$ & $0.34 \pm 0.01 *$ & $0.52 \pm 0.02$ \\
\hline E228K & 3.8 & $3.0(83)$ & $1.72 \pm 0.01 *$ & $1.08 \pm 0.01^{*}$ \\
\hline $\mathrm{D} 262 \mathrm{H}$ & 5.0 & & $0.87 \pm 0.02 *$ & $1.51 \pm 0.03^{*}$ \\
\hline $\mathrm{K} 301 \mathrm{E}$ & 2.5 & $4-4.5(93)$ & $1.40 \pm 0.01^{*}$ & $0.75 \pm 0.02 *$ \\
\hline E228K-K300D & 5.5 & & $0.52 \pm 0.01 *$ & $1.07 \pm 0.03^{*}$ \\
\hline E228K-K300T & NA & & NA & NA \\
\hline E228K-K300R & 4.0 & $3.0(81)$ & $1.44 \pm 0.23^{*}$ & $0.91 \pm 0.14^{*}$ \\
\hline E228K-K300R-K301E & 4.0 & & $4.00 \pm 0.05 *$ & $1.11 \pm 0.02^{*}$ \\
\hline E228K-K300T-K301E & $3.0-4.0$ & & $2.25 \pm 0.03^{*}$ & $1.06 \pm 0.05^{*}$ \\
\hline E228K-K300D-K301E & 4.0 & $3.0(95)$ & $2.28 \pm 0.03^{*}$ & $0.93 \pm 0.03^{*}$ \\
\hline K94E-E228K & 4.5 & $3.0(78)$ & $0.69 \pm 0.04 *$ & $0.79 \pm 0.04^{*}$ \\
\hline K94E-E228K-K301E & $2.5-4.5$ & & $1.38 \pm 0.07^{*}$ & $0.81 \pm 0.04 *$ \\
\hline K94E-K300E-K301E & $3.0-4.0$ & & $12.68 \pm 0.14^{*}$ & $1.07 \pm 0.01^{*}$ \\
\hline K300E-K301E & $3-4.5$ & & $6.62 \pm 0.11^{*}$ & $1.11 \pm 0.03^{*}$ \\
\hline K91A-E228Q-K300E & $4.5-5$ & & $0.70 \pm 0.05^{*}$ & $1.53 \pm 0.11^{*}$ \\
\hline $\begin{array}{l}\text { K94A-E228A-D262A- } \\
\text { K300D }\end{array}$ & 5.5 & & $0.55 \pm 0.02 *$ & $0.94 \pm 0.04^{*}$ \\
\hline
\end{tabular}

${ }^{a}$ Relative activity at the second optimal $\mathrm{pH}$, as at the first optimal $\mathrm{pH}$, is expressed as a percentage in parentheses.

${ }^{b}$ The ratios of phytase activity at different $\mathrm{pH}$ pairs are expressed as mean \pm standard error ( $n=3$ to 6 ). The buffer conditions were as follows: $\mathrm{pH} 5.5,0.2 \mathrm{M}$ citrate; $\mathrm{pH} 3.5,0.2 \mathrm{M}$ glycine-HCl; $\mathrm{pH} 2.5,0.2 \mathrm{M}$ glycine-HCl. An asterisk indicates a difference $(P<0.05)$ from the WT. NA, not applicable.

amount of activity that released $1 \mu \mathrm{mol}$ of inorganic phosphorus from sodium phytate per minute at $\mathrm{pH} 5.5$ and $37^{\circ} \mathrm{C}$. The enzyme was diluted in $0.2 \mathrm{M}$ citrate buffer, $\mathrm{pH} 5.5$, and an equal volume of substrate solution containing $1 \%$ sodium phytate (Sigma) was added. After incubation of the sample for $15 \mathrm{~min}$ at $37^{\circ} \mathrm{C}$, the reaction was stopped by addition of an equal volume of $15 \%$ trichloroacetic acid. The released inorganic phosphorus was determined as previously described (30). The total protein concentration in the samples was determined by the method of Lowry et al. (17). Samples of the purified proteins were subjected to $10 \%$ sodium dodecyl sulfate-polyacrylamide gel electrophoresis using a MiniProtean II cell (Bio-Rad Laboratories, Hercules, CA) (12) and Western blot analysis (8).

The initial $\mathrm{pH}$ profiles of the expressed phytases were determined using the following buffers (at $\mathrm{pH} 0.5$ intervals): $0.2 \mathrm{M}$ glycine- $\mathrm{HCl}$ for $\mathrm{pH} 2$ to $3.5,0.2 \mathrm{M}$ citrate for $\mathrm{pH} 4$ to 6.5 , and $0.2 \mathrm{M}$ Tris- $\mathrm{HCl}$ for $\mathrm{pH} 7$ to 8.5 . The exact optimal $\mathrm{pH}$ and the $\mathrm{pH}$ profile of the overall best mutant phytase were compared with those of the wild-type (WT) PhyA using $0.2 \mathrm{M}$ glycine- $\mathrm{HCl}$ for $\mathrm{pH}$ 2.0, 2.5, 3.0, 3.2, 3.4, $3.5,3.6,3.8$, and 4.0 and $0.2 \mathrm{M}$ citrate for $\mathrm{pH} 3.5,3.6,3.8,4.0,4.2,4.5,5.0,5.5$, 6.0, and 6.5. Purified enzymes were diluted with each buffer of different $\mathrm{pH}$ to give an activity of $0.1 \mathrm{U} \mathrm{ml}^{-1}$ and mixed with $1 \%$ sodium phytase dissolved in the same buffer at an equal volume $(0.5 \mathrm{ml}$ each $)$ to start the hydrolysis reaction. The released inorganic $\mathrm{P}$ and the relative phytase activity were determined as described above.

Kinetics and phytate hydrolysis profile. The Michaelis-Menten parameters, $V_{\max }$ and $K_{m}$, were determined by incubation of the phytase enzyme $(100 \mathrm{mU}$ at $\mathrm{pH} 5.5$ and 3.5 , respectively) with sodium phytate substrate at $37^{\circ} \mathrm{C}$ in $0.2 \mathrm{M}$ glycine- $\mathrm{HCl}$ buffer, $\mathrm{pH} 3.5$, and in $0.2 \mathrm{M}$ citrate buffer, $\mathrm{pH} 5.5$. A total of 10 different substrate concentrations ranging from 0.1 to $10 K_{m}$ were used, and the reactions were sampled at $0,1,2,3,5$, and $10 \mathrm{~min}$. Initial velocities were calculated from linear regions of the hydrolysis curve and plotted against the inorganic-phosphate concentration. Linear transformation was achieved using Lineweaver-Burk plots to estimate $V_{\max }$ and $K_{m}$ parameters $(3,39)$. The hydrolysis profiles of sodium phytate by the phytase samples were analyzed by highperformance liquid chromatography (HPLC) (Dionex Liquid Chromatograph System DX600; Dionex Corp., Sunnyvale, CA). Phytase was incubated at $37^{\circ} \mathrm{C}$ in an assay mixture containing $0.2 \mathrm{M}$ citrate buffer $(\mathrm{pH} 5.5$ ) or glycine- $\mathrm{HCl}$ buffer $(\mathrm{pH} 3.5)$ and $10 \mathrm{mM}$ sodium phytate. The reaction was stopped after 2, 5, 10, 15, $20,30,40,50,60,75$, and $90 \mathrm{~min}$ by adding an equal volume of $15 \%$ trichloroacetic acid solution, and $25 \mu \mathrm{l}$ of 1:10-diluted samples or standards was analyzed using an AS11 ion-exchange column (Dionex Corp., Sunnyvale, CA) and a flow rate of $1 \mathrm{ml} \mathrm{min}^{-1}$ with a gradient of 26 to $70 \mathrm{mM} \mathrm{NaOH}$ and detected by a conductivity detector (Dionex ED50).

Hydrolysis of phytate-phosphorus in soybean meal. The effectiveness in releasing phytate phosphorus from soybean meal was measured by incubating the feed sample with phytase (a $250-\mathrm{U} \mathrm{kg}^{-1}$ sample) in $0.2 \mathrm{M}$ citrate buffer, $\mathrm{pH} 5.5$, and in $0.2 \mathrm{M}$ glycine- $\mathrm{HCl}, \mathrm{pH} 3.5$ and 2.5 , respectively, at $37^{\circ} \mathrm{C}$ for $1 \mathrm{~h}$. One gram of soybean meal was dissolved in $9 \mathrm{ml}$ buffer and incubated at $37^{\circ} \mathrm{C}$ for $20 \mathrm{~min}$ with shaking. Then, $1 \mathrm{ml}$ of prewarmed diluted enzyme was added to start the hydrolysis reaction. After $1 \mathrm{~h}$ of incubation at $37^{\circ} \mathrm{C}$ with shaking, the reaction was stopped by the addition of an equal volume of $15 \%$ trichloroacetic acid. The released inorganic phosphorus was determined as previously described (31).

Animal feed trial. The Institutional Animal Care and Use Committee of Cornell University approved the protocol for the animal experiments. After being fed a low-phosphorus corn-soybean meal basal diet (34), 16 weanling pigs (28 days old) were fed the same basal diet supplemented with E228K $(n=8)$ or WT PhyA phytase $(n=8)$ at $250 \mathrm{U} \mathrm{kg}$ of feed ${ }^{-1}$ for 35 days. The growth performance, plasma inorganic-phosphorus concentrations, and plasma alkaline phosphatase activities of individual pigs were determined weekly as previously described (34).

Statistical analysis. Data were analyzed by SAS (release 6.04; SAS Institute, Cary, NC), and the Bonferroni $t$ test was used to compare mean differences. Significance was set at a $P$ value of $<0.05$.
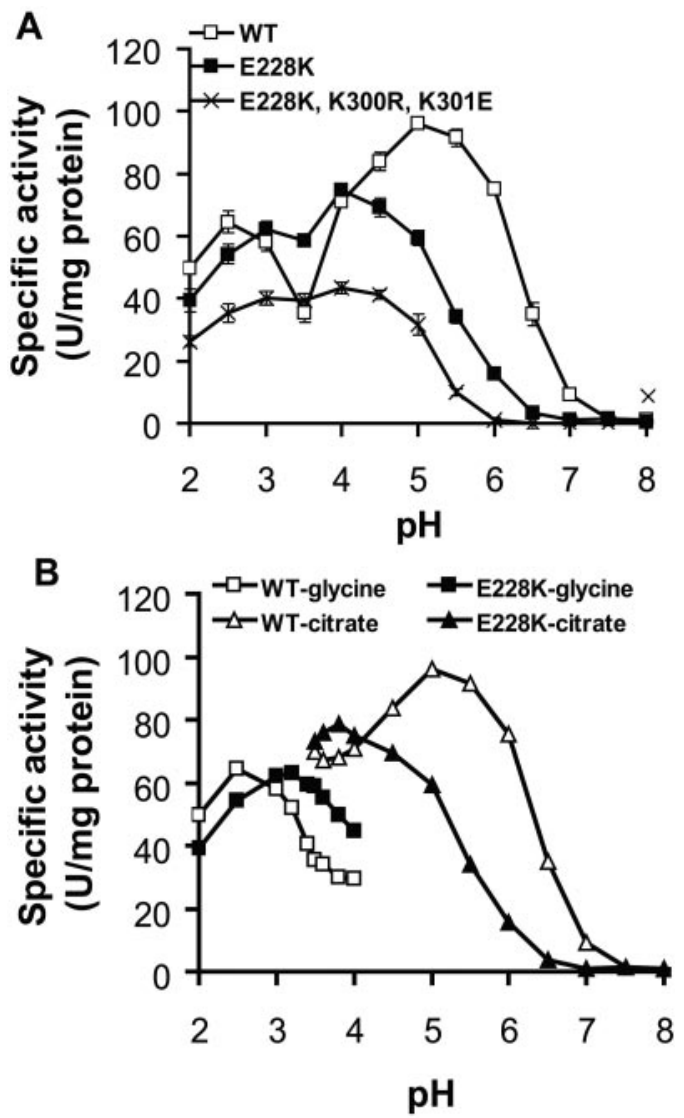

FIG. 2. Comparisons of $\mathrm{pH}$ profiles of the WT, the single mutant E228K, and the triple mutant E228K-K300R-K301E. In both panels, values are expressed as the mean specific activity \pm standard error $(n=3)$ (for panel B, standard errors were too small to be seen) of the purified enzymes at each $\mathrm{pH}$, and phytase activity was determined using sodium phytate dissolved in the designated assay buffer. (A) $\mathrm{pH}$ 2.0 to $3.5,0.2 \mathrm{M}$ glycine- $\mathrm{HCl}$; $\mathrm{pH} 4.0$ to $6.5,0.2 \mathrm{M}$ citrate; and $\mathrm{pH} 7.0$ to $8.0,0.2 \mathrm{M}$ Tris-HCl. (B) $\mathrm{pH} 2.0$ to $4.0,0.2 \mathrm{M}$ glycine- $\mathrm{HCl} ; \mathrm{pH} 3.5$ to $6.5,0.2 \mathrm{M}$ citrate. Overlapping $\mathrm{pH}$ points between the two buffer systems and smaller intervals were used to compare the buffer effect and the exact optimal $\mathrm{pH}$ of the testing phytases. 


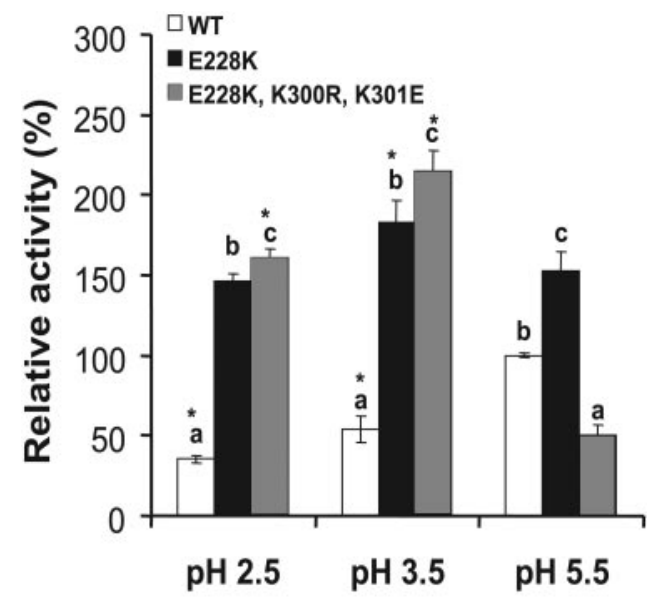

FIG. 3. Efficacies of phytate-phosphorus hydrolysis in soybean meal by the single mutant E228K and the triple mutant E228K-K300R$\mathrm{K} 301 \mathrm{E}$ at $\mathrm{pH} 2.5(0.2 \mathrm{M}$ glycine- $\mathrm{HCl}), 3.5(0.2 \mathrm{M}$ glycine- $\mathrm{HCl})$, and 5.5 $(0.2 \mathrm{M}$ citrate) $)$ at $37^{\circ} \mathrm{C}$ compared with that of the WT. The hydrolysis rates were calculated as the percentage of the WT phytase at $\mathrm{pH} 5.5$, and the values are means \pm standard errors $(n=3)$. An asterisk indicates a difference $(P<0.05)$ between $\mathrm{pH} 5.5$ and other $\mathrm{pH}$ values within each enzyme. Different letters indicate differences $(P<0.05)$ between the WT and the mutants within each $\mathrm{pH}$ point.

\section{RESULTS}

Shifts of pH optima and profile in PhyA mutants. Transformants of all mutants except the double mutant E228K-K300T expressed extracellular phytase activity in the medium supernatants. The impacts of all mutations on the $\mathrm{pH}$ optima and the relative activity ratios at $\mathrm{pH} 3.5$ versus at $\mathrm{pH} 5.5$ or $\mathrm{pH} 2.5$ (the two pH optima of the WT enzyme) are summarized in Table 1. The WT PhyA showed the unique bihump two-pHoptima profile, whereas 12 mutants lost one $\mathrm{pH}$ optimum and 14 mutants had the $\mathrm{pH}$ optimum shifted from $\mathrm{pH} 5.5$ to the more acidic side. Compared with the WT enzyme, 15 mutants exhibited higher $(P<0.05)$ activities at $\mathrm{pH} 3.5$ than at $\mathrm{pH} 5.5$ or 2.5 .

The initial $\mathrm{pH}$ profile assay indicated that E228K showed the best overall catalytic improvement among all single mutants (Fig. 2A). The optimal $\mathrm{pH}$ was shifted to 4 , and the activity trough at $\mathrm{pH} 3.5$ was essentially eliminated. This resulted in a 1.7-fold-higher phytase activity at $\mathrm{pH} 3.5$ than the WT, which is about $38 \%$ of the activity found at $\mathrm{pH} 5.5$. The mutant had similar activities at $\mathrm{pH} 3.5$ and 2.5 , while the WT had only $55 \%$ activity at $\mathrm{pH} 3.5$ compared to the activity level at $\mathrm{pH} 2.5$. Further $\mathrm{pH}$ profile analysis, with smaller intervals adjacent to critical points and overlapping ranges between two different buffers, showed $\mathrm{pH} 3.8$ and 5 as the optimal pHs for E228K and the WT PhyA, respectively (Fig. 2B). When the glycine$\mathrm{HCl}$ buffer was used, E228K displayed higher specific activity than the WT PhyA between pH 3.0 and 4.0. The opposite was true when the citrate buffer was used between $\mathrm{pH} 3.5$ and 6.5. Among the multiple mutants, TK10 (E228K-K300R-K301E) showed the most favorable shift of optimal pH to 3 to 4 and a large increase in the phytase activity ratio at $\mathrm{pH} 3.5$ over $\mathrm{pH} 5.5$ to $4.00 \pm 0.05$, with slightly more activity at $\mathrm{pH} 3.5$ than at 2.5 (ratio, $1.11 \pm 0.02$ ) (Fig. 2A and Table 1). Two other mutants (K94E-K300E-K301E and K300E-K301E) showed greater improvement in relative activity at $\mathrm{pH} 3.5$ (Table 1) but had low
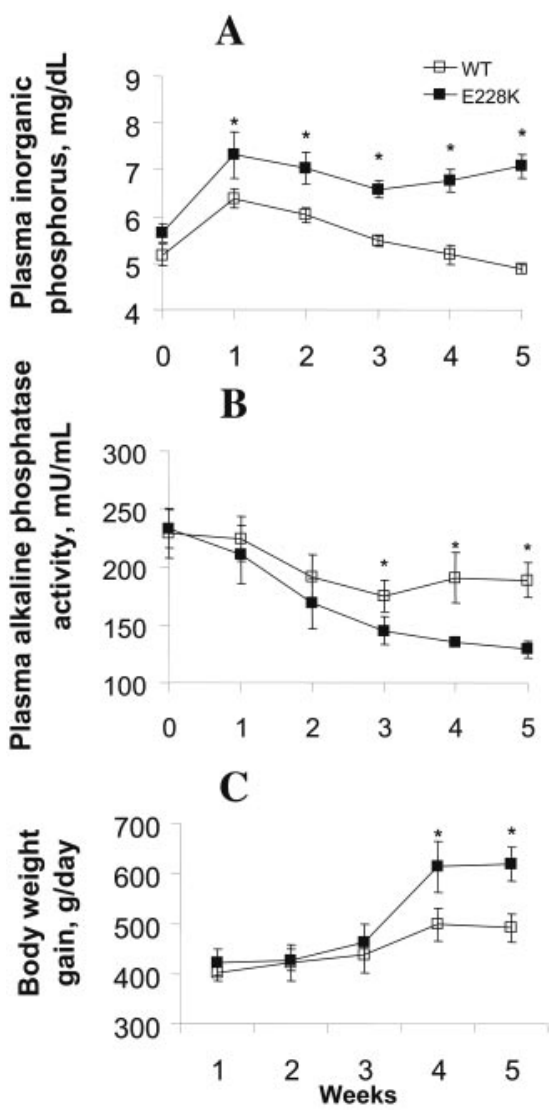

FIG. 4. Effects of supplemental E228K and WT PhyA phytases at $250 \mathrm{U} \mathrm{kg}^{-1}$ of a low-phosphorus corn-soybean meal diet for weanling pigs on plasma inorganic-phosphorus concentrations (A), plasma alkaline phosphatase activity (B), and body weight gain (C). The values are means \pm standard errors $(n=8$ for each group). An asterisk indicates a difference $(P<0.05)$ between treatment groups.

specific activity or yield (data not shown). The molecular size, glycosylation, reactivity to polyclonal antibody against the purified PhyA protein from $A$. niger, optimal temperature, and heat stability of these two and other mutants were not significantly different from those of the WT (data not shown).

In vitro and in vivo functional assays. Because soybean meal is the major source of phytate in animal diets, we used it to compare the hydrolysis efficacies of the native phytate substrate by mutants E228K and TK10 with that of the WT. Given the same activity as

TABLE 2. Comparison of kinetics of the WT and E228K mutant PhyA phytases $^{a}$

\begin{tabular}{llcccc}
\hline pH & Phytase & $\begin{array}{c}K_{m} \\
(\mu \mathrm{M})\end{array}$ & $\begin{array}{c}V_{\max } \\
\left(\mu \mathrm{mol} \mathrm{m}^{-1}\right. \\
\left.\mathrm{mg}^{-1}\right)\end{array}$ & $\begin{array}{c}k_{\text {cat }} \\
\left(\mathrm{m}^{-1}\right)\end{array}$ & $\begin{array}{c}k_{\text {cat }} / K_{m} \\
\left(\mathrm{~m}^{-1}\right. \\
\left.\mu \mathrm{M}^{-1}\right)\end{array}$ \\
\hline 5.5 & WT & $177.3 \pm 22.4$ & $94.7 \pm 5.4$ & $7,385.3 \pm 421.1$ & 41.64 \\
& E228K & $38.6 \pm 13.2^{*}$ & $34.5 \pm 3.9^{*}$ & $2,690.2 \pm 304.1^{*}$ & $69.71^{*}$ \\
3.5 & WT & $321.9 \pm 37.9$ & $33.8 \pm 5.4$ & $2,638.4 \pm 421.1$ & 8.20 \\
& E228K & $227.8 \pm 18.5^{*}$ & $62.1 \pm 3.9^{*}$ & $4,844.3 \pm 304.1^{*}$ & $21.27^{*}$ \\
\hline
\end{tabular}

${ }^{a}$ Enzymatic reactions $(n=3)$ were conducted at $37^{\circ} \mathrm{C}$ in $0.2 \mathrm{M}$ glycine-HCl buffer for $\mathrm{pH} 3.5$ and in $0.2 \mathrm{M}$ citrate buffer for $\mathrm{pH} 5.5$ using various sodium phytate concentrations $\left(0.1\right.$ to $\left.10 K_{m}\right)$ and $100 \mathrm{mU}$ phytase (purified) per ml reaction mixture. An asterisk indicates a difference $(P<0.05)$ from the WT. 

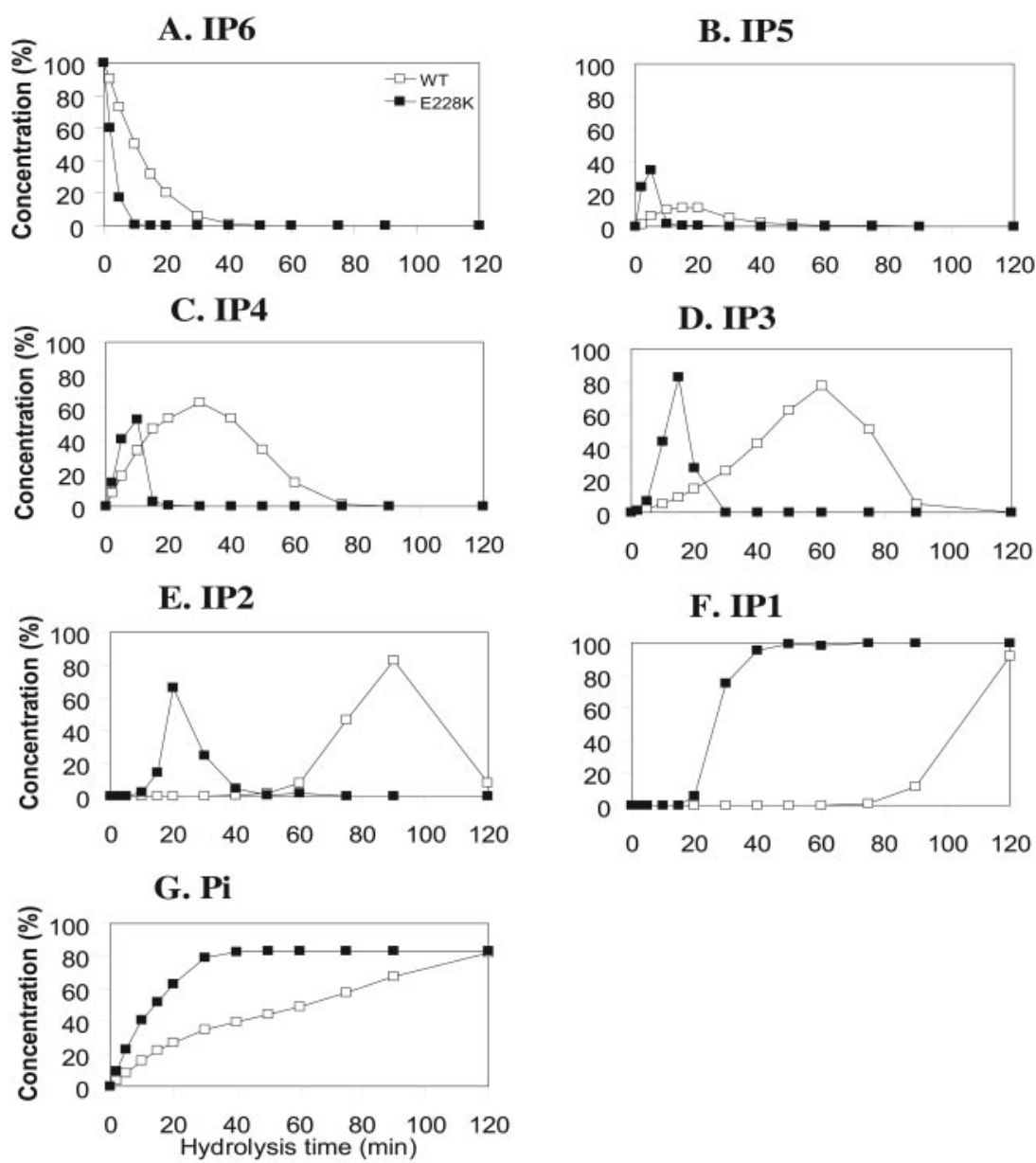

FIG. 5. Time courses of phytate hydrolysis by the WT and mutant E228K PhyAs and the subsequent appearance and disappearance of the intermediate or end products from the hydrolysis. The values are expressed as the concentration relative to the possible complete (maximal) hydrolysis. The enzymes $\left(2 \mathrm{U} \mathrm{ml}^{-1}\right)$ were incubated with $1 \%$ sodium phytate in $0.2 \mathrm{M}$ glycine- $\mathrm{HCl}$ buffer, $\mathrm{pH} 3.5$, for the designated times, and the hydrolytic metabolites were analyzed by HPLC. (A) Inositol hexaphosphate (IP6); (B) inositol pentaphosphate (IP5); (C) inositol tetraphosphate (IP4); (D) inositol triphosphate (IP3); (E) inositol diphosphate (IP2); (F) inositol monophosphate (IP1); (G) inorganic phosphate (Pi).

determined at $\mathrm{pH} 5.5$ using sodium phytate as the substrate, mutant E228K released 313, 238, and 53\% more $(P<0.05)$ inorganic phosphorus from soy phytate at $\mathrm{pH} 2.5,3.5$, and 5.5, respectively, than the WT (Fig. 3). Meanwhile, the TK10 mutant showed an improved $(P<0.05)$ efficiency at $\mathrm{pH} 2.5$ and 3.5 but decreased efficiency at $\mathrm{pH} 5.5 \mathrm{com}-$ pared to the WT. When the WT and E228K enzymes were added to the low-phosphorus corn-soy basal diet for weanling pigs at $250 \mathrm{U} \mathrm{kg}^{-1}$ and fed to these pigs for 5 weeks, the mutant $(\mathrm{E} 228 \mathrm{~K})$ phytase resulted in $13 \%$ higher (451 versus $509 \mathrm{~g} ; P<0.05$ ) average daily body weight gain and 15 to $30 \%$ higher $(P<0.05)$ plasma inorganic-phosphorus concentration at weeks 2 to 5 than the WT enzyme (Fig. 4). Pigs fed E228K mutant phytase also had lower $(P<$ $0.05)$ plasma alkaline phosphatase activities than those fed the WT at weeks 3 to 5 , indicating less bone phosphorus resorption.

Kinetics characterization and hydrolysis profiles of the mutant phytase. To elucidate the enzymatic basis for the improved efficacy of E228K over the WT in soy phytate hydrolysis and animal feed, we determined their kinetic parameters, $V_{\max }$ and $K_{m}$, for the hydrolysis of sodium phytate at $\mathrm{pH} 5.5$ and 3.5 (Table 2). Compared to the WT, the $K_{m}$ values of E228K for sodium phytate were 79 and $30 \%$ lower $(P<0.05)$ at pH 5.5 and 3.5, respectively. This resulted in 70 and $160 \%$ greater overall catalytic efficiency $\left(k_{\text {cat }} / K_{m}\right)$ at these two $\mathrm{pH}$ levels for E228K phytase. The HPLC analysis of the phytate hydrolysis profile at pH 3.5 (Fig. 5) had indicated that, although both the WT and E228K hydrolyzed sodium phytate to inositol 2-monophosphate and inorganic phosphate as the final products, the process took $120 \mathrm{~min}$ for the WT phytase but only $40 \mathrm{~min}$ for the mutant enzyme (Fig. 5). A delayed or much slower hydrolysis of inositol tetraphosphate and inositol triphosphate in the WT compared with E228K was particularly evident. There were also improvements in phytate hydrolysis by the E228K mutant phytase at $\mathrm{pH} 5.5$ over the WT (data not shown). In addition, the E228K mutant enzyme had higher catalytic activity to smaller and synthetic substrates, such as $p$-nitrophenyl phosphate, phospho(enol)pyruvate, and fructose-6-monophosphate than the WT phytase (data not shown). 


\section{DISCUSSION}

The most striking success in this study was in proving the feasibility of shifting the $\mathrm{pH}$ profile of a practically important enzyme, phytase, to enhance its catalytic efficiency in the digestive tract of a major food-producing species (swine). Among the 21 mutants, E228K showed the greatest overall improvement. The single amino acid alteration resulted in shifting the optimal $\mathrm{pH}$ from 5.5 to 3.8 with a significant rise in the relative activity at $\mathrm{pH} 3.5$ compared with the WT. More importantly, this mutant was more efficient than the WT in releasing phytate-phosphorus from plant feed in vitro or in the gastrointestinal tracts of pigs. Two possible mechanisms may be used to explain these desirable changes. First, the substitution of a positively charged lysine at the 228 residue might affect the $\mathrm{pK}_{\mathrm{a}}$ of the acid/base catalyst (D362) indirectly, resulting in a shift of the optimal $\mathrm{pH}$. Theoretically, introducing positive charges near the acid/base catalyst lowers the $\mathrm{pK}_{\mathrm{a}}$ value and shifts the optimal $\mathrm{pH}$ to a more acidic range (24). Second, the substitution of a positively charged lysine for the negatively charged glutamic acid may create a more favorable environment for the binding of the highly negatively charged substrate, phytate, by electrostatic attraction. Altogether, the substrate binding affinity at the acidic $\mathrm{pH}$ range for this mutant was improved markedly, as confirmed by the reduced $K_{m}$ of phytate at $\mathrm{pH} 3.5$. Conversely, replacing E228 with a neutral amino acid (E228Q) negated the benefit derived from inserting lysine in the same position. However, it was somewhat surprising that the mutant also had improved hydrolysis of soy phytate at $\mathrm{pH} 5.5$ compared to the WT. At pH 5.5, E228 might be protonated and interact with phytate by an $\mathrm{H}$ bond only, while the positively charged $228 \mathrm{~K}$ could bind phytate by both an $\mathrm{H}$ bond and electrostatic interactions. This increased substrate affinity was reflected in the reduction in the $K_{m}$ values. Because phytate concentrations in the soybean meal $(0.39 \%$ or $0.35 \mathrm{mM}$ in the solution) and the swine $\operatorname{diet}(0.27 \%$ or $0.49 \mathrm{mM}$ in the stomach) were lower than the substrate concentrations of sodium phytate $(1 \% ; 9 \mathrm{mM})$ used in standard laboratory assays for phytase activity, a lower $K_{m}$ could help the enzyme function under those conditions. Although the average $\mathrm{pH}$ in the stomachs of pigs is around 3.5 (42), part of newly ingested digesta may remain at somewhat higher $\mathrm{pH}$ levels before fully mixing with gastric fluids (29). Thus, there is an extra benefit for E228K in having a relatively strong catalytic efficiency at $\mathrm{pH} 5.5$, along with the other favorable changes. Apparently, the greater efficacy of E228K in animal feed was attributable to the matching of the optimal $\mathrm{pH}$ to the stomach conditions, the improved substrate affinity and hydrolysis, and a net gain instead of a loss of efficiency in hydrolyzing soy phytate at $\mathrm{pH} 5.5$ when the overall $\mathrm{pH}$ profile was shifted to the more acidic side. In addition, the higher specific activity of E228K than the WT PhyA in glycine- $\mathrm{HCl}$ buffer between $\mathrm{pH} 3.0$ and 4.0 would allow the variant to perform better hydrolysis of phytate in the stomach, where the $\mathrm{pH}$ is around 3.5 and the gastric acid is predominately $\mathrm{HCl}$ (42).

Notably, E228K had better substrate specificity for low-molecular-weight phosphatase substrates, such as inositol di-, tri, and tetraphosphates, than the WT. Although without a structural model of the PhyA substrate (10) it is difficult for us to explain why the mutation in E228K resulted in a particular ability to hydrolyze these intermediate metabolites, the shorter time (40 versus $120 \mathrm{~min}$ ) needed for hydrolysis of phytate to inositol monophosphate and inorganic phosphate by E228K than by the WT certainly helped the release of phytate in the digesta, which had limited transition time in the stomach. It is remarkable that the mutation in E228K made it not only a better phytase, but also a stronger acid phosphatase for several substrates. However, this observation does not support the notion (11) that the catalytic function of PhyA phytase depends on the extent of phosphorylation of myo-inositol.

Our second important finding deals with altering of $\mathrm{pH}$ versus the activity profile by mutating key residues in the substrate-binding domain. Previously, we showed that the replacement of negatively charged amino acids at the 300th amino acid residue (300E-300D) resulted in the optimal $\mathrm{pH}$ shift from 2.5 to 3 or 3.5 (22). Likewise, replacement of Q50L, K91E, or $\mathrm{E} 262 \mathrm{H}$ in the present study abolished the $\mathrm{pH} 2.5$ optimum. The residues K94 and E228 may also be involved in the activity at $\mathrm{pH} 2.5$, as the replacement of K94E and E228K caused a shift of the activity peak at $\mathrm{pH} 2.5$ to 2.0 or 3 . Meanwhile, $\mathrm{K} 301$, the most conserved amino acid in the known phytase proteins (22), seems to be important for the catalytic activity and the substrate binding affinity at $\mathrm{pH}$ 5.5. The replacement of lysine with glutamic acid resulted in negative changes in both of the parameters (data not shown), probably due to the undesirable electrostatic repulsion between the enzyme and the substrate and between 301E and 362D (acid/base catalyst) (data not shown). Mutations of Q50L, Q50P, and D262H narrowed the $\mathrm{pH}$ optimum at 5 to 5.5 to a single point of $\mathrm{pH} 5$ or 5.5. As mentioned above, the replacement of E228K led to a shift of the $\mathrm{pH}$ optimum to 3.8 and greater activity at $\mathrm{pH} 3.5$. However, that change could be affected by combined mutations at residue 300: a positively charged residue 300R rendered the same $\mathrm{pH}$ profile as E228K, and a negatively charged residue $300 \mathrm{D}$ resulted in a single optimal $\mathrm{pH}$ at $\mathrm{pH} 5.5$. When three single mutations, K91A, E228Q, and K300E, were combined, their interaction resulted in a single optimal $\mathrm{pH}$ at 4.5 to 5 , although each single mutant had no or little effect on the $\mathrm{pH}$ profile. Accumulation of negative charges in the substrate binding site, such as K94E, K300E, and K301E, caused a dramatic activity decrease at $\mathrm{pH} 5.5$, and the activity drop seemed to be proportional to the number of negative charges. In summary, the negatively charged amino acids in the substrate binding site had a negative effect on the catalytic efficiency at a $\mathrm{pH}$ around 5.5, probably due to undesirable electrostatic repulsion between the enzyme and the substrate. This supports the hypothesis of Kostrewa et al. (11) about the effect of the charge distribution within the active site on the $\mathrm{pH}$ profiles of $A$. niger acid phosphatase and phytase. However, the effects of charges at low $\mathrm{pH}$ depend on their location and interaction with neighboring amino acids, because those negatively charged amino acids are protonated and have no net charge (6). In addition, the local environment of the charged amino acids also affects the $\mathrm{pK}_{\mathrm{a}}$ of the acid/base catalyst, resulting in a shift in the optimal pH. The residues (E228, K300, and K301) reside close to the acid/base catalyst (D362); therefore, they could affect its $\mathrm{pK}_{\mathrm{a}}$ and the $\mathrm{pH}$ profile of the enzyme (23).

The triple mutant E228K-K300R-K301E showed a very impressive $\mathrm{pH}$ profile shift and more efficient hydrolysis of soy phytate at pH 2.5 and 3.5 than the WT. However, its specific activity was lower than that of the WT at all pH levels except 
$\mathrm{pH}$ 3.5. Thus, the catalytic improvement at $\mathrm{pH} 2.5$ or 3.5 was associated with a much-reduced efficiency at $\mathrm{pH}$ 5.5. There was no net gain, but an actual loss of overall efficiency. This scenario teaches us the need for both in vivo and in vitro functional assays to evaluate genetically modified or engineered enzymes.

In summary, our research has clearly demonstrated that rational protein engineering can be applied to improve the $\mathrm{pH}$-activity profile of phytase for optimal function in the gastrointestinal tracts of animals. The desirable shift in the optimal $\mathrm{pH}$ and the $\mathrm{pH}$ profile, along with an improved substrate affinity, in the overall best mutant was produced by the substitution of a positively charged lysine for the negatively charged glutamic acid at the 228th residue (E228K). Development of this phytase variant will enhance the field application of phytase for improving utilization of phytate-phosphorus in animal feeds, reducing the need for inorganic-phosphorus supplementation and phosphorus and preserving the nonrenewable inorganic-phosphorus deposits. Because of the great similarities between human and pig digestive systems and nutrient metabolisms (20), our results may be able to assist in the remediation of phytate-associated mineral deficiency in humans (27).

\section{ACKNOWLEDGMENTS}

We thank Laurence Heller and Jeremy Weaver for technical assistance.

This project was developed in part under the auspices of the Cornell University Center for Biotechnology.

\section{REFERENCES}

1. Abelson, P. H. 1999. A potential phosphate crisis. Science 283:2015.

2. Augspurger, N. R., D. M. Webel, X. G. Lei, and D. H. Baker. 2003. Efficacy of an E. coli phytase expressed in yeast for releasing phytate-bound phosphorus in young chicks and pigs. J. Anim. Sci. 81:474-483.

3. Bisswanger, H. 2002. Enzyme kinetics, principles and methods, p. 51-74. Willey-VCH, Weinheim, Germany.

4. Cottrell, T. J., L. J. Harris, T. Tanaka, and R. Y. Yada. 1995. The sole lysine residue in porcine pepsin works as a key residue for catalysis and conformational flexibility. J. Biol. Chem. 270:19974-19978.

5. Fang, T. Y., and C. Ford. 1998. Protein engineering of Aspergillus awamori glucoamylase to increase its pH optimum. Protein Eng. 11:383-388.

6. Fushinobu, S., K. Ito, M. Konno, T. Wakagi, and H. Matsuzawa. 1998. Crystallographic and mutational analyses of an extremely acidophilic and acid-stable xylanase: biased distribution of acidic residues and importance of Asp37 for catalysis at low pH. Protein Eng. 11:1121-1128.

7. Golovan, S. P., R. G. Meidinger, A. Ajakaiye, M. Cottrill, M. Z. Wiederkehr, D. J. Barney, C. Plante, J. W. Pollard, M. Z. Fan, M. A. Hayes, J. Laursen, J. P. Hjorth, R. R. Hacker, J. P. Phillips, and C. W. Forsberg. 2001. Pigs expressing salivary phytase produce low-phosphorous manure. Nat. Biotechnol. 19:741-745.

8. Han, Y. M., D. B. Wilson, and X. G. Lei. 1999. Expression of an Aspergillus niger phytase gene $(p h y A)$ in Saccharomyces cerevisiae. Appl. Environ. Microbiol. 65:1915-1918.

9. Joshi, M. D., G. Sidhu, I. Pot, G. D. Brayer, S. G. Withers, and L. P. McIntosh. 2000. Hydrogen bonding and catalysis: a novel explanation for how a single amino acid substitution can change the $\mathrm{pH}$ optimum of a glycosidase. J. Mol. Biol. 299:255-279.

10. Kostrewa, D., F. Grüninger-Leitch, A. D'Arcy, C. Broger, D. Mitchell, and A. P. G. M. van Loon. 1997. Crystal structure of phytase from Aspergillus ficuum at $2.5 \AA$ resolution. Nat. Struct. Biol. 4:185-190.

11. Kostrewa, D., M. Wyss, A. D'Arcy, and A. P. G. M. van Loon. 1999. Crystal structure of Aspergillus niger $\mathrm{pH} 2.5$ acid phosphatase at $2.4 \AA$ resolution. J. Mol. Biol. 288:965-974.

12. Laemmli, U. K. 1970 . Cleavage of structural proteins during the assembly of the head of bacteriophage T4. Nature 227:680-685.

13. Lei, X. G., P. K. Ku, E. R. Miller, and M. T. Yokoyama. 1993. Supplementing corn-soybean meal diets with microbial phytase linearly improves phytate phosphorus utilization by weanling pigs. J. Anim. Sci. 71:3359-3367.

14. Lei, X. G., and C. H. Stahl. 2001. Biotechnological development of effective phytases for mineral nutrition and environmental protection. Appl. Microbiol. Biotechnol. 57:474-481.
15. Li, C., E. Hegeman, R. W. Hanlon, G. H. Lacy, M. D. Denbow, and E. A. Grabau. 1997. Secretion of active recombinant phytase from soybean cellsuspension cultures. Plant Physiol. 114:1103-1111.

16. Lim, D., S. Golovan, C. W. Forsberg, and J. Jia. 2000. Crystal structure of Escherichia coli phytase and its complex with phytate. Nat. Struct. Biol. 72:108-113.

17. Lowry, O. H., N. J. Rosebrough, A. L. Farrr, and R. J. Randall. 1951. Protein measurement with the folin phenol reagent. J. Biol. Chem. 193:265-275.

18. Maga, J. A. 1982. Phytate: its chemistry, occurrence, food interactions, nutritional significance, and methods of analysis. J. Agric. Food Chem. 30:1-9.

19. Mantafounis, D., and J. Pitts. 1990. Protein engineering of chymosin: modification of the optimum pH of enzyme catalysis. Protein Eng. 3:605-609.

20. Miller, E. R., and D. E. Ullrey. 1987. The pig as a model for human nutrition. Annu. Rev. Nutr. 7:361-382.

21. Mullaney, E. J., C. B. Daly, and A. H. J. Ullah. 2000. Advances in phytase research. Adv. Appl. Microbiol. 47:157-199.

22. Mullaney, E. J., C. B. Daly, T. Kim, J. M. Porres, X. G. Lei, K. Sethumadhavan, and A. H. J. Ullah. 2002. Site-directed mutagenesis of Aspergillus niger NRRL 3135 phytase at residue 300 to enhance catalysis at $\mathrm{pH}$ 4.0. Biochem. Biophys. Res. Commun. 277:1016-1020.

23. Nielsen, J. E., T. V. Borchert, and G. Vriend. 2001. The determinants of $\alpha$-amylase $\mathrm{pH}$-activity profiles. Protein Eng. 14:505-512.

24. Ostanin, K., E. H. Harms, P. E. Stevis, R. Kuciel, M. M. Zhou, and R. L. van Etten. 1992. Overexpression, site-directed mutagenesis, and mechanism of Escherichia coli acid phosphatase. J. Biol. Chem. 267:22830-22836.

25. Ostanin, K., and R. L. van Etten. 1993. Asp (304) of Escherichia coli acid phosphatase is involved in leaving group protonation. J. Biol. Chem. 268: 20778-20784.

26. Pallauf, J., and G. Rimbach. 1997. Nutritional significance of phytic acid and phytase. Arch. Anim. Nutr. 50:301-319.

27. Porres, J. M., P. Etcheverry, D. D. Miller, and X. G. Lei. 2001. Phytase and citric acid supplementation in whole wheat bread improves phytate-phosphorus release and iron dialyzability. J. Food Sci. 66:614-619.

28. Reddy, N. R., S. K. Sathe, and D. K. Salukhe. 1982. Phytates in legumes and cereals. Adv. Food Res. 28:1-92.

29. Rice, J. P., R. S. Pleasant, and J. S. Radcliffe. 2002. The effect of citric acid, phytase, and their interaction on gastric $\mathrm{pH}$, and $\mathrm{Ca}, \mathrm{P}$, and dry matter digestibilities, p. 36-42. Purdue University Swine Research Report. Purdue University, West Lafayette, Ind.

30. Rodriguez, E., E. J. Mullaney, and X. G. Lei. 2000. Expression of the Aspergillus fumigatus phytase gene in Pichia pastoris and characterization of the recombinant enzyme. Biochem. Biophys. Res. Commun. 268:373-378.

31. Rodriguez, E., Z. A. Wood, P. A. Karplus, and X. G. Lei. 2000. Site-directed mutagenesis improves catalytic efficiency and thermostability of Escherichia coli pH 2.5 acid phosphatase/phytase expressed in Pichia pastoris. Arch. Biochem. Biophys. 382:105-112.

32. Russell, A. J., P. G. Thomas, and A. R. Fersht. 1987. Electrostatic effects on modification of charged groups in the active site cleft of subtilisin by protein engineering. J. Mol. Biol. 193:803-813.

33. Spencer, J. D., G. L. Allee, and T. E. Sauber. 2000. Phosphorus bioavailability and digestibility of normal and genetically modified low-phytate corn for pigs. J. Anim. Sci. 78:675-681.

34. Stahl, C. H., K. R. Roneker, W. G. Pond, and X. G. Lei. 2004. Effects of combining three fungal phytases with a bacterial phytase on plasma phosphorus status of weanling pigs fed a corn-soy diet. J. Anim. Sci. 82:17251731 .

35. Tomschy, A., M. Tessier, M. Wyss, R. Brugger, C. Broger, L. Schnoebelen, A. P. G. M. van Loon, and L. Pasamontes. 2000. Optimization of the catalytic properties of Aspergillus fumigatus phytase based on the three-dimensional structure. Protein Sci. 9:1304-1311.

36. Tomschy, A., R. Brugger, M. Lehmann, A. Svendsen, K. Vogel, D. Kostrewa, S. F. Lessen, D. Burger, A. Kronenberger, A. P. G. M. van Loon, L. Pasamontes, and M. Wyss. 2002. Engineering of phytase for improved activity at low pH. Appl. Environ. Microbiol. 68:1907-1913.

37. Turunen, O., M. Vuorio, F. Fenel, and M. Leisola. 2002. Engineering of multiple arginines into the Ser/Thr surface of Trichoderma reesei endo-1,4$\beta$-xylanase II increases the thermotolerance and shifts the $\mathrm{pH}$ optimum towards alkaline pH. Protein Eng. 15:141-145.

38. Ullah, A. H. J., and D. M. Gibson. 1987. Extracellular phytase (E. C. 3. 1. 3. 8) from Aspergillus ficuum NRRL 3135: purification and characterization. Prep. Biochem. 17:63-91.

39. Ullah, A. H. J., and B. Q. Phillipy. 1994. Substrate selectivity in Aspergillus ficuum phytase and acid phosphatases using myo-inositol phosphates. J. Agric. Food Chem. 42:423-425.

40. Ullah, A. H. J., K. Sethumadhavan, E. J. Mullaney, T. Ziegelhoffer, and S. Austin-Phillips. 2002. Cloned and expressed fungal phyA gene in alfalfa produces a stable phytase. Biochem. Biophys. Res. Commun. 290:1343-1348.

41. Wodzinski, R. J., and A. H. J. Ullah. 1996. Phytase. Adv. Appl. Microbiol. 42:263-302.

42. Yi, Z., and E. T. Kornegay. 1996. Sites of phytase activity in the gastrointestinal tract of young pigs. Anim. Feed. Sci. Technol. 61:361-368. 